\title{
Eksistensi tradisi Sekaten di Yogyakarta terhadap integerasi dalam beragama di masyarakat Kecamatan Godomanan, Kotamadya Yogyakarta, Provinsi DIY, tahun 2020
}

\author{
Muhammad Kresna Dutayana, Irawan* \\ Universitas Negeri Malang, Jl. Semarang No. 5 Malang, Jawa Timur, Indonesia \\ *Penulis korespondensi, Surel: irawan.fis@um.ac.id
}

Paper received: 01-05-2021; revised: 15-05-2021; accepted: 30-05-2021

\begin{abstract}
In the Sekaten tradition, it has a cause and effect from the existence of integration in society, in which the existence of the Sekaten tradition in Yogyakarta is there an influence on integration in religion and diversity in Yogyakarta society. This article in its discussion uses qualitative research, using data triangulation techniques with observation, interviews, and documentation. Sampling using quota sampling, to 20 residents from Godomanan District. From the results obtained, it is explained that the Sekaten tradition can create integration in religion and diversity in society.
\end{abstract}

Keywords: Sekaten tradition; integration; in religion/diversity

\begin{abstract}
Abstrak
Dalam tradisi Sekaten mempunyai sebab akibat dari adanya integrasi dalam masyarakat, yang mana eksistensi tradisi Sekaten di Yogyakarta apakah ada pengaruh terhadap integrasi dalam beragama maupun keberagamaan di masyarakat Yogyakarta. Artikel ini dalam pembahasannya menggunakan penelitian kualitatif, menggunakan teknik triangulasi data dengan observasi, wawancara, dan dokumentasi. Pengambilan sampel menggunakan quota sampling, kepada 20 warga dari Kecamatan Godomanan. Dari hal hasil yang didapatkan menjelaskan jika tradisi Sekaten ini bisa menciptakan integrasi dalam beragama maupun keberagamaan di masyarakat.
\end{abstract}

Kata kunci: tradisi Sekaten; integrasi; dalam beragama/keberagaman

\section{Pendahuluan}

Dalam masyarakat Yogyakarta terdapat suatu tradisi yang berkaitan dengan hal keagamaan, apa lagi terdapat tradisi keagamaan yang perpaduan dengan adat daerah tersebut. Tradisi keagamaan ini sudah menjadi sebuah acara resmi dalam peringatan keagamaan dan telah menyatukan masyarakat setempat, sehingga adanya konektivitas antar sesama dalam tradisi tersebut. Tadisi yang dimaksud adalah tradisi Sekatenan atau Maulid Nabi yang telah melekat pada masyarakat di Yogyakarta, pada acara hari besar keagamaan selain adanya hari raya umat Islam yaitu Idul Fitri dan Idul Adha. Di Dalam acara Sekatenan ini ada Grebeg, namun ada juga di acara peringatan hari besar umat Islam yang lainnya. Menjadikan adanya Grebeg yang melekat dalam acara Idul Fitri, Idul Adha, Muharram, Syawal, Besar dan Mulud. Namun pada hal ini terpusat pada Grebeg Maulud yang tentunya memiliki karakteristik tersendiri dengan acara Grebeg hari besar keagamaan yang lainnya.

Penyebarluasan ajaran agama Islam terlihat pada acara Grebeg ini, Pareden setelah didoakan kemudian dibagikan untuk masyarakat. Pembagian Pareden (dirayah) dilakukan di halaman masjid Agung, dahulu kegiatan ini sebagai bentuk syiar Islam di Yogyakarta. Awalnya tradisi Sekatenan ini diperkenalkan oleh seorang Wali Songo yang bernama Sunan Kalijaga, yang selanjutnya memberikan pengaruh bagi masyarakat umat Islam di Yogyakarta. Walaupun 
demikian penyebaran tradisi Sekatenan ini juga ada di wilayah Solo, yang maknanya juga sama untuk memperingati hari lahir Nabi Muhammad SAW atau Maulid Nabi. Sunan Kalijaga juga berinovasi dalam bidang pertanian yaitu dengan menggabungkan hasil bumi ke dalam tradisi Grebeg Maulud dan Sekaten, dua institusi spiritual yang dimanfaatkan Sunan untuk melakukan dakwah dengan pendekatan budaya (Beratha, 1982). Dari tradisi Sekaten tersebut mempunyai fungsi untuk terwujudnya integrasi dalam kolektivitas masyarakat dalam beragama, khususnya untuk menyatukan umat Islam agar saling mempererat tali persaudaraan. Apalagi dalam tradisi Sekaten telah menyatukan masyarakat umat Islam untuk hidup rukun dan damai, juga memberikan imbas untuk bertoleransi antar umat dalam beragama jika umat non muslim ingin mengikuti Grebeg Sekaten.

Eksistensi Sekaten berkaitan dengan tata nilai dari lingkungan masyarakat setempat yang biasanya berhubungan dengan kesuburan-kemakmuran, keselamatan, dan kerukunan antarwarga. Kultur lokal dan kultur modern seakan melebur dalam waktu bersamaan dalam momentum Sekaten (Utami, 2011). Upacara Sekaten tidak hanya dihadiri oleh warga masyarakat Yogyakarta saja namun masyarakat dari berbagai daerah juga sangat antusias untuk menghadiri upacara ini, diantara mereka ada yang hadir untuk mendengarkan ceramah agama Islam di depan Masjid Besar dan tidak sedikit pula yang datang untuk ngalap berkah (Sapphira, 2019). Ngalap Berkah adalah acara memperebutkan gunungan dan udhik-udhik, mereka yang antusias terhadap acara ngalap berkah percaya bahwa gunungan dan udhik-udhik yang diperebutkan mempunyai kekuatan supranatural (Suyami, 2008). Jadi Sekaten merupakan upacara tradisional berkaitan dengan sistem kepercayaan atau religi (Soepanto, 1991), yang dimana tradisi ini merupakan bagian dari ritual adat umat Islam.

Untuk pembahasan penelitian mengenai eksistensi tradisi Sekaten di Yogyakarta, terhadap integrasi dalam beragama di masyarakat Yogyakarta, mengalami sedikit kekurangan dalam kajiannya. Mengapa demikian, sebab tidak menjelaskan secara spesifik perbedaan Grebeg Sekaten dengan Grebeg hari besar Umat Islam yang lainnya. Grebeg dalam acara hari besar umat Islam yang lainnya yaitu hari raya Idul Fitri, hari raya Idul Adha, Muharram, Syawal, dan Mulud. Juga kekurangannya tidak bisa menggabungkan penjelasan yang seimbang untuk menuntaskan penjelasan tradisi Sekaten di Surakarta, apalagi dalam pembahasan pada topik ini tidak bisa membandingkan tradisi Sekaten di Yogyakarta dan Surakarta lebih spesifik. Fokus utama yang diteliti yaitu eksistensi tradisi Sekaten yang bisa mengintegrasi masyarakat beragama di Yogyakarta, sehingga adanya persatuan dan kedamaian dalam umat Islam juga adanya toleransi antar umat beragama. Hal tersebut terlihat jika eksistensi Sekaten berkaitan dengan tata nilai dari lingkungan masyarakat setempat yang biasanya berhubungan dengan kesuburan-kemakmuran, keslametan, dan kerukunan antarwarga. Jadi tujuan spesifik penelitian ini yaitu ingin mengetahui seberapa besar eksistensi tradisi Sekaten di Yogyakarta terhadap integrasi dalam beragama maupun keberagamaan di masyarakat Yogyakarta. Konteks sosial subjek dan lokasinya yaitu tradisi Sekaten terhadap integrasi dalam beragama di lingkup masyarakat Yogyakarta, untuk menganalisis datanya terpusat pada masyarakat di wilayah Kecamatan Godomanan, Kotamadya Yogyakarta, Provinsi Daerah Istimewa Yogyakarta.

\section{Metode}

Pada penelitian ini mengambil lokasi di wilayah Kecamatan Godomanan, Kotamadya Yogyakarta, Provinsi Daerah Istimewa Yogyakarta. Subjek yang dibicarakan disini adalah eksistensi tradisi Sekaten terhadap integrasi dalam beragama di masyarakat Kecamatan 
Godomanan, Provinsi Yogyakarta. Sedangkan untuk konteks sosialnya berpusat pada integrasi dalam masyarakat yang beragama dan keberagaman. Untuk waktu penelitiannya sendiri berlangsung kurang lebih satu bulan untuk terjun kelapangan dan mengumpulkan data-data sekunder berupa studi pada penelitian terdahulu, tepatnya pada bulan Desember tahun 2020. Penerapan metode dalam penelitian tersebut menggunakan metode penelitian kualitatif, yang berarti suatu penelitian yang ditujukan untuk mendeskripsikan dan menganalisis fenomena, peristiwa, aktivitas sosial, sikap, kepercayaan, persepsi, pemikiran orang secara individual maupun kelompok. Beberapa deskripsi digunakan untuk menemukan prinsip-prinsip dan penjelasan yang mengarah pada penarikan kesimpulan. Metode penelitian kualitatif ini digunakan dalam penelitian ini sebab ingin mengetahui pandangan dan perilaku tentang masyarakatnya, mengenai eksistensi tradisi Sekaten terhadap integrasi dalam beragama di masyarakat Kecamatan Godomanan, Provinsi Yogyakarta. Sehingga dengan metode kualitatif ini bisa mendapatkan data secara empiris dan dapat teruji kebenarannya secara langsung, serta dapat menggali informasi dalam masyarakat secara luas dan langsung dengan bertanya secara langsung/ wawancara maupun secara kuesioner yang disebarkan ke masyarakat. Juga dari data wawancara mengenai penelitian ini bisa dideskripsikan serta nantinya diberikan penarikan kesimpulan.

Penerapan metode penelitian dilapangan yaitu dengan mencari narasumber yang akan diwawancarai, terutama dalam wawancara ini difokuskan pada pengambilan sampel beberapa orang di Kecamatan Godomanan yang selanjutnya akan diberikan pertanyaan secara terstruktur atau bebas. Setelah mewawancarai, peneliti harus observasi data dengan baik dan mengamati kejadian peristiwa dengan baik atau memberikan pertanyaan yang sesuai. Selanjutnya peneliti akan mendokumentasikannya dari pertanyaan ataupun gambaran langsung penelitian itu yang menggali tentang eksistensi tradisi Sekaten terhadap integrasi dalam beragama di masyarakat Kecamatan Godomanan, kemudian melakukan reduksi data yang telah terkumpul dan melakukan penyajian data ataupun setelah itu validitas data. Pengumpulan datanya sendiri penelitian ini yaitu dengan teknik triangulasi data dengan observasi, wawancara, dan dokumentasi. Dapat dijelaskan dengan kaitanya tema penelitian ini, yaitu:

\subsection{Wawancara}

Wawancara (interview) adalah suatu kejadian atau suatu proses interaksi antara pewawancara (interviewer) dan sumber informasi atau orang yang diwawancarai (interviewe) melalui komunikasi langsung (Yusuf, 2014). Untuk pemilihan informan wawancara ini digunakan teknik pengambilan sampel dengan teknik quota sampling, agar bisa mendapatkan narasumber yang tidak mencakup seluruh populasi penduduk. Serta dengan teknik quota sampling ini bisa mempercepat penelitian dan bisa mewakili pendapat yang sama dengan warga sekitar yang lain. Quota sampling adalah teknik untuk menentukan sampel dari populasi yang mempunyai ciri-ciri tertentu sampai jumlah (kuota) yang diinginkan, teknik ini jumlah populasi tidak diperhitungkan tetapi diklasifikasikan dalam beberapa kelompok dengan memberikan jatah atau quorum tertentu terhadap kelompok dan jika jatah telah terpenuhi maka pengumpulan data dihentikan (Hidayat, 2017).

Jadi untuk penerapan teknik quota sampling untuk mendapatkan narasumbernya dengan mengambil data sejumlah total 20 orang setempat yang terdiri dari, 10 warga Kelurahan Ngupasan dan 10 warga Prawirodirjan. Mengapa hanya ada dua kelurahan saja yang 
diambil, sebab Kecamatan Godomanan hanya ada dua kelurahan yaitu Kelurahan Ngupasan dan Kelurahan Prawirodirjan. Jadi setelah mendapatkan sejumlah 20 warga, maka otomatis wawancara dihentikan setelah mendapatkan sejumlah informan tersebut. Penentuan informan tersebut diambil secara acak, agar nantinya penelitian ini bisa menjangkau keseluruhan dengan tidak adanya keterbatasan waktu. Juga disini tidak harus secara pasti harus mewawancarai pemimpin lurah, sebab pandangan warga sangat dibutuhkan agar bisa mendapatkan data empiris mengenai integrasi tradisi Sekaten dalam beragama maupun keberagamaan di masyarakat. Pada saat melakukan wawancara peneliti sudah meminta persetujuan RT.36/RW.11 Kelurahan Prawirodirjan dan RT.40/RW.11 Kelurahan Ngupasan, yang mana untuk meminta izin mewawancarai warga setempat dan terutama wawancara dengan Bapak atau Ibu RT setempat.

Data yang akan digali dalam informan wawancara tersebut yaitu apa yang dimaksud dengan tradisi Sekatenan di Yogyakarta terhadap pandangan masyarakat Kecamatan Godomanan. Setelah mendapatkan penjelasan tersebut dilanjutkan mengenai bagaimana tradisi Sekatenan di Yogyakarta dapat melekat pada masyarakat yang berpadu dengan ajaran agama umat Islam, maka dari itu warga sekitar bisa memberikan contoh dari penjelasan ajaran tersebut. Juga mempertanyakan bagaimana tradisi Sekaten bisa membuat solidaritas dalam mewujudkan integrasi beragama maupun keberagamaan di masyarakat, serta memberikan contoh mewujudkan integrasi tersebut dan cara menyelesaikan permasalahan mengenai perbedaan di masyarakat yang dapat menimbulkan disorganisasi pada tradisi Sekaten tersebut. Serta menanyakan simbol dari makna dan tujuan dari Sekaten tersebut, serta bisa memberikan penjelasan mengenai integrasi di masyarakatnya dalam keterkaitan dengan tradisi Sekaten. Juga dalam wawancara tersebut ingin mengetahui bagaimana bentuk perilaku dalam tradisi Sekatenan bisa mempersatukan/mengintegrasi masyarakat dalam umat Islam dan antar umat beragama di masyarakat Kecamatan Godomanan. Serta bagaimana tradisi Sekatenan tidak berbenturan dan tidak berdisorganisasi dengan multikultural di masyarakat dan dalam keberagamaan di tengah masyarakat di Kecamatan Godomanan.

\subsection{Observasi}

Observasi berarti mengumpulkan data langsung dari lapangan (Semiawan, 2010), sedangkan menurut Zainal Arifin dalam buku (Kristanto, 2018) observasi adalah suatu proses yang didahului dengan pengamatan kemudian pencatatan yang bersifat sistematis, logis, objektif, dan rasional terhadap berbagai macam fenomena dalam situasi yang sebenarnya maupun situasi buatan. Kunci keberhasilan observasi sebagai teknik pengumpulan data sangat banyak ditentukan pengamat sendiri, sebab pengamat melihat, mendengar, mencium, atau mendengarkan suatu objek penelitian dan kemudian menyimpulkan dari apa yang ia amati itu (Rizkykawasati, 2019). Pengamat adalah kunci keberhasilan dan ketepatan hasil penelitian (Yusuf, 2014).

Penelitian ini menggunakan observasi dalam melakukan penelitian data dilapangan, yang mana dengan observasi ini yang diamati adalah mengenai gambaran prosesi tradisi Sekaten yang dapat dilihatkan melalui foto atau video yang diabadikan warga setempat ataupun acaranya secara langsung. Observasi ini sangat diperlukan agar bisa teruji keempirisan data yang ditemukan melalui pengamatan secara langsung dari penjelasan maupun perilaku dalam prosesi tradisi Sekaten tersebut. Jenis observasi yang digunakan ada dua yaitu observasi non partisipan dan observasi kelompok, mengenai observasi non 
partisipan yaitu pengamatan yang dilakukan tanpa terjun kelapangannya secara langsung. Sehingga peneliti mengembangkan pengamatannya berdasarkan perkembangan yang terjadi di dalam teks atau naskah, jurnal penelitian terdahulu, buku-buku elektronik yang terkait, video, gambar atau foto, film pendek, dan berita majalah di internet. Jadi dalam observasi tersebut peneliti bisa mengembangkan data penelitian dari penelitian terdahulu dan data-data dokumentasi dari acara tradisi sekaten, sehingga bisa terarah dengan baik dalam pencarian datanya secara akurat. Sedangkan untuk observasi kelompok yang digunakan yaitu pengamatan dilakukan oleh sekelompok tim peneliti terhadap sebuah isu yang diangkat menjadi objek penelitian. Menjadikan penelitian dari jurnal maupun skripsi yang telah berupa sekumpulan data bisa dijadikan penunjang data penelitian, sebab hasil penelitiannya itu bisa dijadikan penambah data dilapangan.

\subsection{Dokumentasi}

Metode dokumentasi berarti tata cara pengumpulan data dengan mencatat data-data yang sudah ada, metode dokumentasi juga metode pengumpulan data yang digunakan untuk menelusuri data historis. Dokumen tentang orang atau sekelompok orang, peristiwa, atau kejadian dalam situasi sosial yang sangat berguna dalam penelitian kualitatif (Yusuf, 2014). Teknik atau studi dokumentasi adalah cara pengumpulan data melalui peninggalan arsip-arsip dan termasuk juga buku-buku tentang pendapat, teori, dalil-dalil atau hukum-hukum dan lainlain berhubungan dengan masalah penelitian (Rizkykawasati, 2019). Jadi dalam metode pengumpulan dokumentasi ini peneliti bisa mendapatkan data penelitian mengenai tradisi Sekaten terhadap integrasi dalam beragama maupun keberagamaan di masyarakat Kecamatan Godomanan, dari mendokumentasikan data penelitian dilapangan secara langsung melalui catatan, video, dan foto. Serta bisa mendapatkan data dari penelitian terdahulu melalui kajian pustaka dari jurnal, skripsi, blog internet, buku, dan lain-lain. Untuk mendapatkan data dari buku, jurnal, skripsi, dan sebagainnya ini sangatlah menguntungkan peneliti, apalagi bisa memberikan tambahan data dilapangan dan bisa membantu peneliti untuk tidak kehabisan waktu untuk pengumpulan data yang diperlukan.

Dalam penelitian tersebut analisis data penelitiannya menggunakan tiga jalur pada penelitian kualitatifnya yaitu reduksi data, penyajian data, dan penarikan kesimpulan (Miles \& Huberman, 1992). Penjabaran mengenai tiga tahap analisis data tersebut yaitu: 1) Reduksi data, merupakan bentuk analisis yang menajamkan, menggolongkan, mengarahkan, membuang yang tidak perlu, dan mengorganisasi data dengan cara sedemikian rupa sehingga kesimpulan akhir dapat diambil (Agusta, 2003). Maka dari itu untuk tujuan pelaksanaan reduksi data ini berguna untuk memberikan kerangka data penelitian yang diperoleh melalui meringkas atau memilih data yang digunakan dalam penelitian, sehingga argumen atau data mengenai tradisi Sekaten yang penting untuk dikaji bisa masuk tanpa pencampuran data yang tidak penting. 2) Penyajian Data, yaitu kegiatan ketika sekumpulan informasi disusun, sehingga memberi kemungkinan akan adanya penarikan kesimpulan dan pengambilan tindakan. Bentuk penyajian data kualitatif berupa teks naratif, berbentuk catatan lapangan matriks, grafik, jaringan, dan bagan. Bentuk-bentuk ini menggabungkan informasi yang tersusun dalam suatu bentuk yang padu dan mudah diraih, sehingga memudahkan untuk melihat apa yang sedang terjadi, apakah kesimpulan sudah tepat atau sebaliknya melakukan analisis kembali (Agusta, 2003). 3) Penarikan Kesimpulan, dilakukan peneliti secara terus-menerus selama berada di lapangan. Dari permulaan pengumpulan data, yang dimana memulai mencari arti bendabenda, mencatat keteraturan pola-pola dalam catatan teori, penjelasan-penjelasan, 
konfigurasi-konfigurasi yang mungkin, alur sebab akibat, dan proposisi. Kesimpulankesimpulan ini ditangani secara longgar, tetap terbuka dan skeptis, tetapi kesimpulan sudah disediakan. Mula-mula belum jelas, namun kemudian meningkat menjadi lebih rinci dan mengakar dengan kokoh (Agusta, 2003). Jadi dalam penarikan kesimpulan ini, berguna untuk peneliti bisa memberikan kesimpulan penjelasan mengenai kejadian atau arti dari simbolsimbol tradisi Sekaten. Jadi nanti nya penarikan kesimpulan ini berguna dalam mengartikan makna dan tujuan dari tradisi Sekaten terhadap integrasi, juga memberikan penjelasan yang singkat mengenai tradisi Sekaten dan pada tahap terakhir penelitian ini bisa memberikan penjelasan secara singkat mengenai gambaran, masalah, dan solusi dari tradisi Sekaten terhadap integrasi dalam beragama maupun keberagamaan di masyarakat Kecamatan Godomanan.

\section{Hasil dan Pembahasan}

\subsection{Hasil}

Dalam penelitian mengenai eksistensi tradisi Sekaten di Yogyakarta terhadap integrasi dalam beragama di masyarakat Kecamatan Godomanan, tepatnya di Kelurahan Ngupasan dan Kelurahan Prawirodirjan mendapatkan hasil dari pencarian sumber data wawancara kepada 20 warga dan observasi non partisipan, serta observasi kelompok. Pada kelangsungan tradisi sekaten terdapat korelasi antara kaitanya dengan tradisi Sekaten dan integrasi dalam beragama di masyarakatnya, namun dari hal tersebut mulai dari makna tradisi Sekaten terlebih dahulu sampai ke pokok pembahasan. Untuk hasil yang dijelaskan akan digabungkan dari hasil wawancara kepada 20 warga Kecamatan Godomanan, yang terbagi menjadi 10 warga RT.40/RW.11 Kelurahan Ngupasan dan 10 warga RT.36/RW.11 Kelurahan Prawirodirjan. Dengan hasil observasi non partisipan dan observasi kelompok yang mana, mendapatkan data dari teks, naskah, jurnal ilmiah, jurnal penelitian terdahulu, buku-buku, berita di blog internet, dan lain-lain. Serta dengan pelengkap dokumentasi dari jurnal penelitian terdahulu dan hasil skripsi, serta video/film dan foto/gambar. Tradisi Sekatenan adalah salah satu istilah yang digunakan masyarakat Jawa dalam memperingati hari lahir Nabi Muhammad SAW atau disebut juga dengan istilah Maulid Nabi, yang diakhiri dengan acara Grebeg Maulud (AlFajriyati, 2019). Dalam Sekaten terdapat upacara Garebeg, yang mempunyai arti sebagai sedekah Dalem ini dapat diartikan sebagai wujud syukur pemberian Sultan kepada rakyatnya, bentuk wujud syukur tersebut berupa gunungan yang kemudian di Grebeg (dibawa bersamasama) dan selanjutnya dirayah (diambil) oleh masyarakat (Kuncoro, 2018).

Ritual Sekaten diawali oleh pasar malam selama 35 hari, disambung dengan ritual dibunyikannya 2 perangkat gamelan sekaten milik Kraton selama 7 hari, dan puncaknya adalah pembacaan Risalah Maulid Nabi Muhammad SAW oleh Penghulu Kraton yang dihadiri oleh Sultan Hamengkubuwono X di serambi Masjid Besar Kauman sebelum 2 perangkat gamelan sekaten diboyong kembali ke Kraton (Brata, 2015). Sedangkan proses ritualnya yaitu dimulai dengan dikeluarkannya dua gamelan dari tempat penyimpanannya di Bangsal Sri Manganti yakni Kyai Guntur Madu dan Kyai Naga Wilaga lalu disinggahkan ke Bangsal Ponconiti yang kemudian dengan pengawal para prajurit keraton dibawa ke halaman Masjid Agung Gedhe Kauman dan diakhiri dengan grebeg Gunungan Sekaten (Djojowadono, 1989). Pada penelitian wawancara kepada 20 warga Kecamatan Godomanan terdapat pembaharuan mengenai tradisi Sekaten di dua tahun terakhir ini, yang mana para warga tersebut menjelaskan jika tradisi Sekaten mulai luntur dari masyarakat pada dua tahun terakhir ini yaitu 2019-2020. Hal itu 
terjadi sebab ada yang berubah dari periahan/hiburan, minat, kebersamaan dalam masyarakat yang beragam, jumlah yang hadir dalam tradisi tersebut, dan antusiasme warga untuk menguri-nguri budaya adat. Walaupun prosesi utama adat dari tradisi Sekaten masih ada sampai sekarang, namun ada hal yang mengurang dari periahan, antusiasme warga, kebersamaan warga, dan melestarikan adat dari kalangan muda.

Dijelaskan dari 20 warga Kecamatan Godomanan bahwa sebagian besar mengatakan bahwa pasar malam yang dua tahun dari 2019-2020 tidak diadakan pasar malam di area alunalun utara Keraton Yogyakarta, membuat antusiasme warga untuk datang ke tradisi Sekaten menjadi berkurang. Bahkan sebagian warga terutama kalangan muda sudah menganggap pasar malam Sekaten ini adalah bagian dari tradisi Sekaten yang ada, namun jika diluruskan pasar malam ini hanya sebuah hiburan untuk memeriahkan tradisi Sekaten. Menjadikan dari pasar malam di Sekaten ini hilang menyebabkan jumlah orang dari luar wilayah dan dalam wilayah tersebut menjadi mengurang, sehingga banyak yang mengatakan jika tradisi Sekaten sudah mulai hilang dan ada yang mengatakan Sekaten sekarang ini sudah tidak ada. Dalam tradisi ini juga terlihat dimana sekarang di tahun 2020 sudah tidak membagikan gunungan berisi makanan seperti nasi bungkus, sego gurih, dan lain-lain, yang mana hanya ada gunungan untuk simbolisasi dan nantinya gunungan tersebut hanya dibagikan di wilayah dalam keraton saja. Sehingga dari hal tersebut sekarang minat warga untuk datang untuk bisa mendapatkan gunungan tersebut berkurang. Serta dari jumlah yang hadir dalam pengajian dan tradisi adat Sekaten mengurang baik itu warga dalam wilayah maupun luar wilayah. Upaya melestarikan tradisi Sekaten bagi kalangan muda juga mulai mengurang, dikatakan pada warga Kecamatan Godomanan jika kalangan muda mulai melupakan makna dan tujuan tradisi ini dan sebagian kalangan muda mulai tidak melestarikannya.

Padahal selama ini tradisi Sekaten bisa membuat kebersamaan dalam masyarakatnya, serta memberikan makna bagi masyarakat untuk bisa guyub rukun atau saling toleransi terhadap semua keberagaman. Menurut warga Kecamatan Godomanan selama ini tradisi Sekaten telah membuat antusiasme masyarakat datang untuk melihat dan mengikuti acara tradisi Sekaten, sehingga dari pola tersebut sudah bisa menggambarkan solidaritas masyarakat yang masih kuat. Juga yang datang pada tradisi Sekaten ini bisa dihadiri oleh berbagai antarumat beragama, menjadikan agama lain bisa melihat dan mengikuti tradisi Sekaten. Walaupun agama lain tetap ada pada upacara tradisi Sekaten, namun mereka tidak sampai beribadah layaknya orang Islam, sehingga mereka menunggu sampai ibadah bagi umat Islam selesai. Untuk umat Islam sendiri tidak mempermasalahkan jika ada agama lain yang mengikuti prosesi tradisi ini, namun mereka saling menghormati dan toleransi terhadap antar umat beragama. Menjadikan hal tersebut mencerminkan kesatuan dalam keberagamaan, selain itu dapat membuat kerukunan dan ketentraman dalam kehidupan antar umat beragama. Dari umat Islam sendiri sudah bisa menjadikan tradisi ini menjadi alat pemersatu masyarakat muslim, terutama perbedaan mazhab terhadap mazhab umat Islam yang lain tidak mempermasalahkan tradisi Sekaten. Warga setempat juga mengatakan walaupun tradisi Sekaten itu berasal dari Muhammadiyah, namun masyarakat Nahdlatul Ulama/NU, LDII, dan MUI masih menerima adanya tradisi ini dan tidak mempermasalahkan tradisi Sekaten.

\subsection{Pembahasan}

Dalam penelitian mengenai eksistensi tradisi Sekaten Di Yogyakarta terhadap integrasi dalam beragama di masyarakat Kecamatan Godomanan, Kotamadya Yogyakarta, Provinsi DIY, 
mempunyai pembahasan mengenai korelasi antara tema penelitian ini dengan integrasi di masyarakat dalam beragama maupun keberagamaan, pandangan agama menurut Emile Durkheim, konsep teori dari Herbert Blumer mengenai interaksionisme simbolik, dan konsep teori dari tindakan sosial Max Weber. Penjabarannya keterkaitan antara tema dan topik-topik tersebut yaitu sebagai berikut:

\subsubsection{Integrasi Di Masyarakat Dalam Tradisi Sekaten}

Dalam masyarakat yang majemuk pastinya terdapat perbedaan dan permasalahanpermasalahan yang muncul, apalagi dalam suatu tradisi yang ada di masyarakat hidup dalam keberagaman budaya. Untuk arti dari integrasi yaitu kata integrasi memiliki pengertian penyatuan hingga menjadi kesatuan yang utuh atau bulat dan jika dalam konteks ilmu sosial integrasi sosial adalah suatu kondisi kesatuan hidup bersama dari aneka satuan sistem sosial budaya, berbagai kelompok etnis dan kemasyarakatan, untuk berinteraksi dan bekerjasama, berdasarkan nilai-nilai dan norma-norma dasar bersama guna mewujudkan fungsi sosial budaya yang maju tanpa mengorbankan ciri-ciri kebhinekaan yang ada (Rusdiana, 2014). Menurut Howard Wriggins dalam Rusdiana (2014), menyatakan bahwa integrasi sosial yaitu penyatuan bagian yang berbeda-beda dari suatu masyarakat menjadikan satu keseluruhan yang lebih utuh, atau memadukan masyarakat kecil yang banyak jumlahnya menjadikan satu kesatuan bangsa. Sedangkan menurut Myron Weyner dalam Rusdiana (2014), menyatakan bahwa integrasi sosial merupakan penyatuan kelompok budaya dan kelompok sosial kedalam satu kesatuan wilayah dan dalam pembentukan suatu identitas nasional.

Dalam tradisi Sekaten terdapat budaya adat tersendiri yang berbeda dengan daerah lain, terutama masyarakat di Yogyakarta terdapat berbagai keberagaman dari adanya antar umat beragama, perbedaan tempat daerah, perbedaan ideologi dan lain-lain. Menjadikan tradisi Sekaten ini tetap ada sampai sekarang, sebab diterima oleh berbagai masyarakat. Dalam hasil wawancara dengan 20 warga Kecamatan Godomanan, terdapat penjelasan jika sejauh ini tradisi Sekaten bisa membuat terbentuknya integrasi dalam hal keagamaan dan keberagamaan di masyarakatnya. Integrasi tersebut bisa tercipta akibat, menurut warga setempat tradisi Sekaten bisa menyatukan umat Islam di masyarakat setempat atau luar daerah dalam peringatan Maulid Nabi. Serta dari penjelasan warga yang sudah berusia lanjut mengatakan bahwa tradisi ini sudah bisa menjadi tempat untuk menyebarkan ajaran Islam pertama kali saat dibawa oleh sunan Kalijaga, juga bisa menyatukan umat muslim karena dulu ini tempat untuk mensyahadatkan orang untuk masuk Islam. Namun seiring zaman, dari tahun-ketahun makna syahadatain untuk memasukan orang ke agama Islam, menjadi sebatas tradisi adat yang mempunyai kebudayaan ritual tradisional dan hanya ada pengajian untuk umat muslim. Warga setempat bisa mewujudkan integrasi dari tradisi tersebut sebab, masyarakat bisa saling toleransi terhadap antar umat beragama yang datang pada tradisi tersebut dan saling menghargai terhadap perbedaan.

Tradisi Sekaten ini juga telah membuat integrasi dalam masyarakat dari berbagai aspek kehidupan, dari wawancara warga Kecamatan Godomanan mereka menjelaskan jika tradisi ini membuat masyarakat untuk datang melihat dan mengikuti tradisi ini yang dapat diikuti oleh siapa saja. Baik itu dari antar umat beragama, wilayah daerah luar kota Yogyakarta dan luar provinsi kota Yogyakarta, orang luar negeri, dan lain-lain. Menjadikan masyarakat yang beragam datang ke tradisi ini dan bisa berjalan dengan harmonis dan rukun, sehingga bisa membuat kesatuan dan persatuan di masyarakat. Hal tersebut bisa terjadi akibat dalam tradisi 
ini bisa diikuti siapa saja dan dari daerah mana saja, adanya pembagian tumpeng atau gunungan ke masyarakat, adanya orang yang menghamburkan uang koin untuk disebar ke masyarakat sekitar, dan adanya pentas seni maupun tradisi Sekaten yang lainnya. Juga dalam tradisi Sekaten ini adanya kerumunan masyarakat yang saling toleransi dan menghargai dalam perbedaan, menjadikan bisa membuat integrasi masyarakat. Namun hal tersebut mulai sirna menjadikan tradisi Sekaten ini sepi pengunjung akibat sudah tidak ada tambahan hiburan pada saat Sekaten yaitu pasar malam, yang mana pasar malam mini dulu selalu ada di alun-alun utara Kraton Yogyakarta. Tapi sekarang sudah tidak ada, menjadikan masyarakat enggan untuk datang ke tradisi Sekaten, sebab dengan alasan hanya bisa mengikuti tradisi tersebut tanpa pasar malam.

Menjadikan kurangnya antusias masyarakat untuk datang ke tradisi Sekaten, menyebabkan jumlah yang datang menjadi berkurang dan menyebabkan kesatuan masyarakat untuk menghadiri acara tersebut mulai sedikit. Serta menyebabkan kelestarian adat tradisi Sekaten ini mulai luntur, yang mana disebabkan oleh adanya kalangan muda yang lebih suka dengan hal yang berbau hiburan atau hiburan yang bersifat teknologi yang modern dan hiburan lebih modern. Juga tradisi ini mulai luntur akibat kalangan muda sekarang banyak yang tidak mengerti makna dan tujuan yang sebenarnya dari tradisi ini, ungkapan dari berbagai warga Kecamatan Godomanan. Serta banyak masyarakat yang mulai enggan datang karena sudah bosan dan sudah tidak ada hiburan pasar malam di alun-alun utara Keraton Yogyakarta saat tradisi Sekaten. Menjadikan hal tersebut membuat kesatuan masyarakat mulai melemah dan bahkan membuat lunturnya tradisi Sekaten di masyarakat, sehingga harus adanya semangat untuk menciptakan kesatuan di dalam tradisi ini lebih baik lagi dan meregenerasikan kepada kalangan muda untuk dapat dilestarikan dengan inovasi dan kreasi baru tanpa meninggalkan tradisi lama.

Tradisi Sekaten juga bisa mengintegrasi dalam beragama atau keberagamaan di masyarakatnya, sebab dalam umat Islam sendiri di masyarakat Yogyakarta yang ikut serta dalam tradisi Sekaten sebagian besar menganut organisasi Muhammadiyah. Padahal dalam masyarakat di Yogyakarta tidak semua menganut organisasi Muhammadiyah, yang dimana ada organisasi Nahdlatul Ulama, dan Lembaga Dakwah Islam Indonesia/LDII. Maka walaupun Sekaten berada dalam perbedaan organisasi Islam di masyarakatnya, akan tetapi bisa menyatukan masyarakatnya dengan baik dalam keberlangsungan di dalam tradisi Sekaten tersebut. Hal tersebut sesuai dengan penjelasan dari 20 warga Kecamatan Godomanan, yang mengatakan jika bisa menyatukan berbagai macam organisasi Islam dalam tradisi tersebut.

\subsubsection{Teori Pandangan Agama Menurut Emile Durkheim Dengan Tradisi Sekaten}

Durkheim melihat agama sebagai suatu kreasi sosial "nyata" yang memperkuat solidaritas, melalui kesamaan pandangan masyarakat mengenai moral (Haryanto, 2015). Selain itu, Durkheim membedakan antara agama dan magis. Maksud agama dalam hal ini merupakan ajaran (Islam, Katolik, Kristen, Hindu, Budha, dan sebagainya) yang secara inheren merupakan fenomena kolektif, sementara magis meliputi ritus-ritus dari praktisi individual berdasarkan permintaan klien (bisanya berhubungan dengan sesajen dan dukun). Teori yang dikembangkan Durkheim dalam perspektif fungsionalis yang menekankan pada fungsi agama, bagi Durkheim, fungsi utamanya adalah meningkatkan kohesi dan solidaritas sosial. Unsur kohesi dan solidaritas sosial yang tinggi akan menyebabkan kontrol sosial yang juga kuat (Haryanto, 2015). Jadi pandangan agama menurut Durkheim adalah kolektivitas baik dalam 
pandangannya terhadap dunia (world of view), sistem simbol yang digunakan (totem), ritual yang dilakukan, maupun dalam mempertahankan kesucian (sacred). Namun, kelemahan utama teori Durkheim adalah pandangannya bahwa agama merupakan konstruksi sosial. Pandangan seperti itu tidak relevan dengan realitas beberapa agama samawi seperti Kristen dan Islam. Pada agama-agama tersebut, kebenaran, ajaran, dan hukum-hukum yang menyangkut kehidupan manusia dikonstruksikan Tuhan. Ritual-ritual yang dilakukan dalam agama samawi juga tidak selalu bersifat kolektif.

Pada teori pandangan agama menurut teori Emile Durkheim mengenai teori fungsionalisme agama, yang dimana dalam tradisi Sekaten dalam ajaran agama Islam mempunyai kaitan dengan integrasi dalam beragama maupun keragaman yang menimbulkan solidaritas dalam kolektivitas beragama umat Muslim dan solidaritas antar umat beragama di masyarakat Yogyakarta. Hal tersebut sesuai dengan penjelasan oleh 20 warga Kecamatan Godomanan, yang menyatakan jika dalam tradisi ini bisa membuat solidaritas antar umat beragama dan umat Muslim. Hal tersebut dijelaskan oleh warga tersebut jika dengan adanya kerumunan masyarakat untuk mengikuti acara tradisi Sekaten, yang dihadiri dari berbagai antar umat beragama dan antar daerah. Membuat hal tersebut menjadikan kesatuan dalam keberlangsungan tradisi tersebut, selain itu dengan adanya pembagian makanan dari gunungan dan uang logam yang disalurkan atau dilemparkan kepada masyarakat. Menjadikan masyarakat bisa mewujudkan solidaritas antar sesama, sebab bisa berpartisipasi untuk mengikuti acara tersebut. Bahkan dengan adanya toleransi dan saling menerima perbedaan dalam masyarakat yang datang di tradisi Sekaten, menyebabkan terciptanya kerukunan dan ketentraman. Maka dari itu tradisi Sekaten di Yogyakarta mempunyai unsur kolektivitas sebab dilakukan secara berkelompok atau bersama-sama dan mengintegrasi dalam beragama, bahkan dalam Sekaten tidak hanya mengintegrasi dalam kesamaan dalam beragama namun bisa memberikan persatuan dalam keharmonisan dalam keberagamaan.

Maka dari pandangan agama menurut Durkheim, bisa memberikan jawaban mengenai tradisi Sekaten umat Islam di Yogyakarta yang sudah menjadikan ini sebagai tradisi untuk mengintegrasikan dalam menumbuhkan solidaritas dalam umat Islam dan tentunya untuk memberikan keharmonisan dalam integrasi keberagamaan di masyarakatnya. Untuk arti ritualnya menurut Durkheim, menjelaskan bahwa ritual yang dimaksud adalah budaya adat yang terkombinasi dengan ajaran Islam dalam perayaan Sekaten. Yang mana dalam tradisi Sekaten, terdapat ritual keagamaan berupa adanya menyan, gunungan atau tumpeng, serta adanya gong dan gending. Menjadikan ritual yang bersifat mistis dan tidak sesuai dengan ajaran Islam, dijadikan hanya sebagai simbolisasi yang baik dan tidak menginginkan kemusyrikan. Jadi tradisi Sekaten adalah ritual atau budaya adat di Yogyakarta yang bertujuan untuk memperingati Maulid Nabi, yang dimana dilakukan secara kolektif dalam ajaran umat Islam dan menimbulkan integrasi dalam beragama maupun dalam keberagamaan di masyarakat Yogyakarta. Serta dengan adanya ritual seperti adanya gamelan dan mendoakan gunungan sebelum dibagikan, sebab ingin mengakulturasi antara budaya Hindu dan Islam menjadi kesatuan tanpa menimbulkan dampak negatif. Serta pembacaan doa sebelum dibagikannya gunungan, sebab ingin bersyukur atas limpahan berkah dari pertanian, perkebunan, dan peternakan yang melimpah. 


\subsubsection{Konsep Teori Dari Hebert Blumer Mengenai Interaksionisme Simbolik Pada Sekaten}

Herbert Blumer mendefinisikan interaksionisme simbolik atau teori interaksi simbolik yaitu, sebagai sebuah proses interaksi dalam rangka membentuk arti atau makna bagi setiap individu (Haris \& Amalia, 2018). Jadi dalam proses interaksi di dalam kehidupan manusia memiliki arti dan makna dalam interaksi tersebut, sehingga dari simbol tertentu bisa menggambarkan apa makna yang terpendam maupun makna secara langsung. Biasanya simbol yang tergambarkan melalui makna dan arti dari proses interaksi mempunyai tujuan arahan, bimbingan, perintah, pujian, dan lain-lain.

Dalam kaitanya dengan penelitian yang diangkat mempunyai korelasi yaitu adanya simbol mengenai interaksi yang dilakukan dalam acara tradisi Sekaten yang menjelaskan bahwa tradisi Sekaten mempunyai makna untuk melakukan doa dan memperingati Maulid Nabi. Juga terlihat dari gunungan atau Grebeg Sekaten yang mempunyai arti tersendiri dalam hal ini, terutama untuk mempersatukan masyarakat dalam beragama dan keberagamaan. Itu bisa terlihat ketika pembagian gunungan dan pembagian uang koin yang dihamburkan ke masyarakat untuk diambil secara bersama-sama, menjadikan hal tersebut adalah bentuk simbol untuk mewujudkan kesatuan dalam masyarakat. Serta warga memberikan penjelasan jika orang tersebut mendapatkan makanan nasi gurih yang didapatkan dari gunungan atau tumpengan, dipercaya dapat menambah awet muda. Bahkan adanya tradisi nginang atau makan suruh yang sekarang hanya sedikit ditemui, nginang ini bertujuan untuk membuat gigi bersih dan kuat. Hal itu sangat sesuai jika tradisi Sekaten mempunyai arti simbolik dalam interaksinya sebab berkaitan dengan ajaran Islam terutama untuk memperingati hari lahir Nabi Muhammad SAW, serta untuk mempersatukan umat Islam dan menimbulkan integrasi dalam keberagamaan di masyarakat Yogyakarta. Serta tradisi Sekaten ini tidak luput dari simbolisasi untuk tetap mempertahankan budaya kearifan lokal, yang mana tradisi ini mulai luntur di masyarakatnya. Sebab masyarakat sudah mulai melupakan makna dan tujuan dari tradisi Sekaten, serta kalangan muda yang lebih menyukai hiburan atau budaya yang menampilkan unsur budaya luar negeri atau modern.

\subsubsection{Konsep Teori Dari Tindakan Sosial Max Webber Dengan Tradisi Sekaten}

Teori tindakan sosial Max Weber berorientasi pada motif dan tujuan pelaku, sehingga dengan begitu dapat memahami perilaku setiap individu maupun kelompok. Bahwa masingmasing memiliki motif dan tujuan yang berbeda-beda terhadap sebuah tindakan yang dilakukannya, sehingga teori ini bisa digunakan untuk memahami tipe-tipe perilaku tindakan setiap individu maupun kelompok. Sebagaimana diungkapkan oleh Weber, cara terbaik untuk memahami berbagai kelompok adalah menghargai bentuk-bentuk tipikal tindakan yang menjadi ciri khasnya (Muhlis \& Norkholis, 2016). Sehingga kita dapat memahami alasan-alasan mengapa warga masyarakat tersebut bertindak (Pip Jones, 2003). Weber melakukan klasifikasi dari empat tipe tindakan yang dibedakan dalam konteks motif para pelakunya yaitu: tindakan tradisional, tindakan afektif, rasionalitas instrumental dan rasionalitas nilai (Muhlis \& Norkholis, 2016).

Keterkaitan topik penelitian ini dengan teori tindakan sosial yaitu terlihat bahwa tradisi Sekaten masuk kedalam tindakan sosial menurut Max Webber. Termasuk kedalam tindakan tradisional, yaitu tindakan yang ditentukan oleh kebiasaan-kebiasaan yang sudah mengakar 
secara turun-temurun. Juga menjelaskan mengenai arti dari tindakan sosial dari makna dan tujuan tradisi Sekaten yang dilakukan oleh umat Islam di masyarakat Yogyakarta. Hal itu juga sesuai bahwa tradisi Sekaten memberikan arti tindakan sosial bahwa tradisi ini dilakukan secara turun-temurun dari ajaran Sunan Kalijaga yang memadukan dengan budaya di Yogyakarta, juga sangat kental dengan sifat ke tradisionalnya dalam tradisi tersebut. Dari wawancara warga Kecamatan Godomanan, ditemukan jika tradisi Sekaten itu merupakan akulturasi dari budaya agama Hindu dengan Islam, yang terlihat pada ciri khas gamelan atau gending dan adanya sesajen. Serta dalam tradisi ini awalnya Sunan Kalijaga dalam melakukan penyebaran ajaran Islam dengan menggabungkan hasil pertanian ke dalam gunungan atau tumpeng, yang mana supaya menjadi akulturasi budaya yang baik dan membuat antusiasme warga meningkat untuk masuk ke dalam ajaran Islam. Dari hal ini menunjukan jika ini termasuk kedalam tindakan sosial tradisional, serta tradisi ini merupakan budaya adat lokal yang memberikan kesatuan dan persatuan dalam menyatukan umat Islam dan antarumat beragama. Hal tersebut bisa dilihat jika banyak orang dari mana saja baik itu dari luar kota maupun non Islam, ada dalam tradisi ini. Menjadikan yang mengikuti tradisi ini bukan hanya orang Islam dan dari daerah itu saja, namun juga diikuti oleh berbagai kalangan dari antar umat beragama, berbagai organisasi Islam, serta dari daerah luar kota atau provinsi dan orang dari luar negeri. Hal tersebut menjadi suatu integrasi yang terwujud dalam masyarakat dari sisi budaya adat dan agama, sehingga hal itu menjadikan paduan yang baik di masyarakatnya.

Tindakan sosial juga menggambarkan kesesuaian tentang penggambaran tradisi Sekaten yang dapat memberikan integrasi dalam beragama dan dalam keberagamaan di masyarakat. Teori tindakan sosial menurut Max Webber ini dalam menganalisis masalah penelitian ini yaitu memberikan penjelasan bahwa adanya perilaku integrasi dalam beragama maupun keberagamaan dalam upacara tradisi Sekaten tersebut. Menunjukan bahwa adanya perilaku masyarakat yang mempunyai tujuan dan makna dalam tradisi Sekaten tersebut, sehingga mengetahui ajaran umat Islam dalam tradisi Sekaten tersebut. Jadi dalam tradisi Sekaten di Yogyakarta terdapat perilaku integrasi dalam beragama maupun keberagamaan di masyarakat Yogyakarta, yang terlihat dari adanya berbagai kalangan di masyarakat yang datang dalam tradisi ini. Baik itu dari berbagai organisasi Islam, non muslim/ antar umat beragama, daerah luar kota Yogyakarta, dan orang dari luar negeri bisa hadir dalam tradisi ini. Selain itu dari penjelasan warga masyarakat Kecamatan Godomanan mengatakan bahwa dalam menciptakan integrasi dalam tradisi ini yaitu terlihat ketika adanya pengajian, pembagian gunungan, adanya gamelan dalam tradisi Sekaten, pasar malam yang sekarang mulai tidak ada, dan adanya pembagian uang koin yang dihamburkan kepada masyarakat yang berkumpul untuk mendapatkannya. Menjadikan hal tersebut membuat suatu integrasi yang ada di masyarakat nya, namun sekarang ini integrasi yang ada di dalam tradisi ini mulai pudar akibat masyarakat kalangan muda sebagian tidak melestarikan tradisi ini dan lebih mementingkan hiburan yang modern dari teknologi atau budaya luar negeri. Integrasi yang ada di dalam tradisi ini mulai pudar akibat antusiasme masyarakat yang datang mengurang, akibat dari tidak adanya pasar malam di alun-alun utara Kraton. Menjadikan masyarakat enggan ke tradisi ini, dengan alasan kurang menarik dan membosankan jika tidak ada pasar malam sebab hanya ada tradisi Sekaten saja dan pengajian. Walaupun begitu prosesi adat tradisi Sekaten yang utama masih ada namun hanya sedikit berbeda dalam antusisame masyarakat yang datang mengurang, makna dan tujuan dari tradisi ini sudah dilupakan oleh kalangan muda, serta sebagian kalangan muda mulai tidak melestarikan adat tradisi ini terlihat ketika mulai mengurangnya kalangan muda yang ikut dalam tradisi ini maupun yang 
berpartisipasi hanya melihat tradisi ini dan melupakan makna dan tujuan tradisi Sekaten yang sebenarnya.

\section{Simpulan}

Dari artikel diatas, dalam penelitian mengenai eksistensi tradisi Sekaten Di Yogyakarta terdapat integrasi dalam beragama maupun keberagamaan di masyarakat Kecamatan Godomanan, Kotamadya Yogyakarta, Provinsi DIY, yang mana dalam mencapai hasil ini harus melakukan wawancara kepada 20 warga Kecamatan Godomanan. Terbagi kedalam 10 warga RT.40/RW.11 Kelurahan Ngupasan dan 10 warga RT.36/RW.11 Kelurahan Prawirodirjan, yang mana setelah mendapatkan jawaban mereka bisa dilengkapi dengan data observasi non partisipan, observasi kelompok, dan data-data dokumentasi yang ada. Dalam tradisi Sekaten ini integrasi dalam masyarakatnya bisa didapatkan dari adanya berbagai kalangan di masyarakat yang datang dalam tradisi ini, baik itu dari berbagai organisasi Islam, non muslim/ antar umat beragama, daerah luar kota Yogyakarta, dan orang dari luar negeri bisa hadir dalam tradisi ini. Menjadikan hal tersebut membuat tradisi Sekaten ini, bisa mengintegrasi masyarakat dalam beragama maupun keberagamaan di dalam tradisi ini. Selain itu dari penjelasan warga masyarakat Kecamatan Godomanan mengatakan bahwa dalam menciptakan integrasi dalam tradisi ini yaitu terlihat ketika adanya pengajian, pembagian gunungan, adanya gamelan dalam tradisi Sekaten, pasar malam yang sekarang mulai tidak ada, dan adanya pembagian uang koin yang dihamburkan kepada masyarakat yang berkumpul untuk mendapatkannya. Menjadikan hal tersebut membuat suatu integrasi yang ada di masyarakat nya, namun sekarang ini integrasi yang ada di dalam tradisi ini mulai pudar akibat masyarakat kalangan muda sebagian tidak melestarikan tradisi ini dan lebih mementingkan hiburan yang modern dari teknologi atau budaya luar negeri.

Integrasi yang ada di dalam tradisi ini mulai pudar akibat antusiasme masyarakat yang datang mengurang, akibat dari tidak adanya pasar malam di alun-alun utara Kraton. Menjadikan masyarakat enggan ke tradisi ini, dengan alasan kurang menarik dan membosankan jika tidak ada pasar malam sebab hanya ada tradisi Sekaten saja dan pengajian. Walupan begitu prosesi adat tradisi Sekaten yang utama masih ada namun hanya sedikit berbeda dalam antusisame masyarakat yang datang mengurang, makna dan tujuan dari tradisi ini sudah dilupakan oleh kalangan muda, serta sebagian kalangan muda mulai tidak melestarikan adat tradisi ini terlihat ketika mulai mengurangnya kalangan muda yang ikut dalam tradisi ini maupun yang berpartisipasi hanya melihat tradisi ini dan melupakan makna dan tujuan tradisi Sekaten yang sebenarnya.

Artikel ini juga mengkaji teori dari pandangan agama menurut Emile Durkheim, mengenai integrasi di dalam tradisi Sekaten di Yogyakarta terhadap kolektivitas dalam beragama ataupun keberagamaan di masyarakat Yogyakarta. Serta mengkaji ritual dan spiritual mengenai tradisi Sekaten terhadap pandangan agama menurut Emile Durkheim, juga kolektivitas dan solidaritas di dalam integrasi pada tradisi Sekaten dalam beragama dan keberagamaan di masyarakat Yogyakarta. Mengenai simbol-simbol makna dari tradisi Sekaten juga dipelajari, sehingga mengerti maksud dan tujuan dari tradisi Sekaten tersebut. Serta artikel ini juga sudah mengkaitkan mengenai teori Herbert Blumer, tentang interaksionisme simbolik pada keberlangsungan tradisi Sekaten pada terwujudnya integrasi dalam keagamaan dan keberagamaan dalam masyarakat. Juga telah berhasil dalam mengaitkan tindakan sosial Max Webber, yang menjelaskan jika tradisi Sekaten termasuk kedalam tindakan tradisional sebab tradisi ini sudah turun-temurun dari masyarakat dahulu. Menjadikan eksistensi tradisi 
Sekaten dalam mewujudkan integrasi dalam beragama maupun keberagamaan, tidak luput dari adanya keberadaan hal yang bersifat tradisional yang mengarah kepada tindakan tradisional menurut Max Webber.

\section{Daftar Rujukan}

Agusta, I. (2003). Teknik Pengumpulan dan Analisis Data Kualitatif. Pusat Penelitian Sosial Ekonomi. Litbang Pertanian, Bogor, 27.

Al-Fajriyati, M. I. (2019). Pengaruh Tradisi Sekatenan Terhadap Perilaku Keagamaan Masyarakat Yogyakarta. Khazanah Theologia, 1(1), 40-46.

Beratha, I. N. (1982). Desa Masyarakat Desa dan Pengembangan Desa. Jakarta: Ghalia Indonesia.

Brata, N. (2015). Religi Jawa dan Remaking Tradisi Grebeg Kraton, Sebuah Kajian Antropologi. Jurnal Sejarah dan Budaya, 2(2).

Djojowadono, D. (1989). Kraton dan Daerah Istimewa Yogyakarta. Yogyakarta: YIPKP Lembaga Javanologi.

Haris, A., \& Amalia, A. (2018). Makna Dan Simbol Dalam Proses Interaksi Sosial (Sebuah Tinjauan Komunikasi). Jurnal Dakwah Risalah, 29(1), 16-19.

Haryanto, S. (2015). Sosiologi Agama dari Klasik Hingga Postmodern. Yogyakarta: Ar-Ruzz Media.

Hidayat, A. (2017). Teknik Sampling Dalam Penelitian (Penjelasan Lengkap). https://www.statistikian.com/2017/06/teknik-sampling-dalam penelitian.html\#d_Cluster_Sampling_Area_Sampling. (diakses 24 Oktober 2020).

Kristanto, V. H. (2018). Metodologi Penelitian Pedoman Penulisan Karya Tulis Ilmiah (KTI). Yogyakarta: CV Budi Utama.

Kuncoro, Y. A. (2018). Komunikasi Ritual Garebeg di Keraton Yogyakarta. Jurnal Aspikom, 3(4), 623-634.

Miles, M. B., \& Huberman, A. M. (1994). Qualitative data analysis: An expanded sourcebook. Sage.

Muhlis, A., \& Norkholis, N. (2016). Analisis Tindakan Sosial Max Weber dalam Tradisi Pembacaan Kitab Mukhtashar Al-bukhari (Studi Living Hadis). Jurnal Living Hadis, 1(2), 242258.

Jones, P. (2003). Pengantar Teori-Teori Social: Dari Teori Fungsionalisme Hingga PostModernisme. (trj.) Saifuddin. Jakarta: Pustaka Obor.

Rizkykawasati, R. (2019). Teknik Pengumpulan Data Metode Kualitatif.

Rusdiana, A. (2014). Integrasi pendidikan agama islam dengan sains dan teknologi. Istek, 8(2), 123-143.

Sapphira, R. N. (2019). Partisipasi Masyarakat Kampung Kauman pada Tradisi Sekaten di Keraton Yogyakarta (Doctoral dissertation, Fakultas Ilmu Budaya).

Soepanto, S., \& Sularto, B. (1991). Upacara Tradisional Sekaten Daerah Istimewa Yogyakarta. Yogyakarta: Departement P dan K.

Semiawan, C. R. (2010). Metodei Penelitian KualitatifJenis, Karakteristik dan Keunggulannya. Jakarta: Grasindo.

Suyami, S. (2008). Upacara Ritual di Keraton Yogyakarta: Refleksi Mithologi dalam Budaya Jawa. Yogyakarta: Kepel Press.

Utami, H. E. (2011). Kidung Sekaten Antara Religi dan Ritus Sosial Budaya. Harmonia: Journal of Arts Research and Education, 11(2).

Yusuf, A. M. (2014). Kuantitatif, Kualitatif, \& Penelitian Gabungan. Jakarta: Kencana. 